\title{
An innovation Systems Approach to Sustainability Transitions Between Qatar and Jordan by Using SAP Software System
}

\author{
Khaloud AL-SULAITI ${ }^{1}$,Houda ALEQEDAT ${ }^{2 *}$ \\ ${ }^{1,2}$ Business and administration Department, Szent Istvan University, Pater Karoly u. 1, Godollo, Hungary
}

\begin{abstract}
A B S T RAC T
This paper aimed to discuss how and where SAP software system can be used. It addresses relevant areas including linear innovation model, multi-level perspective, innovation systems and factors of innovation, factors of innovation, innovation management, circular economy, sustainability transitions, and SAP software system in terms of history, use, digital circular economy business model toolkit, and the difference between linear SAP and circular SAP solutions. It also compares the use of SAP in Qatar and Jordan.
\end{abstract}

A R T I C L E I N F O

Keywords:

SAP software system,

Innovation,

Qatar,

Jordan.
*Corresponding Author E-mail: hudaeqedat@yahoo.com

Copyright (C) 2018Authors. This is an open access article distributed under the Creative Commons Attribution License, which permits unrestricted use, distribution, and reproduction in any medium, provided the original work is properly cited.

\section{INTRODUCTION}

This paper discusses different areas associated with employing technology and innovation in business to maintain a sustainable environment by reducing the consumption of natural resources and relevant costs. First, it discusses the Linear Innovation Model which is based on four key processes: research, development, production, and diffusion. Then, it discusses innovation systems and factors of innovation with a focus on the definition, innovation systems, factors of innovation and innovation management. After that, it discusses the circular economy and sustainable development as well as sustainability transitions. Finally, it discusses SAP software system and its applications and uses in Qatar and Jordan in both sectors public and private.

\section{Problem statement}

To identify to what extent of employing technology and innovation of using SAP system within the organization.

\section{Research objective}

1. Maintaining the sustainable environment by technology and innovation in business. Which is helps to reduce the cost and develop the work process.

2. Consider the importance of applying an 
innovation that SAP system which runs various that develop work procedures within organizations.

\section{LITERATURE REVIEW}

\section{Linear Innovation Model}

Different ideas associated with innovation have been witnessing changes recently. The linear innovation model is regarded as one a key developed framework to recognize technology and science, especially about the economy. This model assumes basic research is required to begin with innovation, then applied research and development are added to go through production and then diffusion.

Researchers, entrepreneurs-developers and producers play a very important role in the innovation process according to this model. Other players who play a role in innovation are shareholders, banks, suppliers, funding organizations, governmental organizations, and customers. This model is beneficial for the companies that follow a systematic approach in developing their productions to enhance their diffusion. It firstly requires making basic research on areas of interest then applied research might be required especially in tested services or products to have in-depth knowledge and information about them. After that, development takes places to solve problems and enhance outputs (Godin, 2005).

\section{Multi-level Perspective}

Multi-level Perspective (MLP) is a middle-range framework which emerged to analyse the sociotechnical transitions to sustainability. However, it has been criticized for different areas such as lacking agency, bias toward bottom-up change model, methodology, and operationalization (Geels, 2011).

Three separate levels determine this model: regime, niche, and landscape. Regime (Meso) is related to the dominant practices, rules, and technologies which provide reinforcement and stability to the prevailing socio-technical systems. The technological regimes are considered a set of rules which are embodied in infrastructure and institutions which form the technological innovations. Niche (Micro) represents the area or level at which there is a space for more experimentation and radical innovation. This level helps facilitate interaction among actors which support the innovation of products. It helps to provide a safe environment for development. The third level is Landscape (Marco) which is related to the overall socio-technical setting which comprises the intangible aspects of the social values as well as the political beliefs and world view and the tangible facets of marketplace like costs, prices, and income and trade patterns (Miles, 2014).

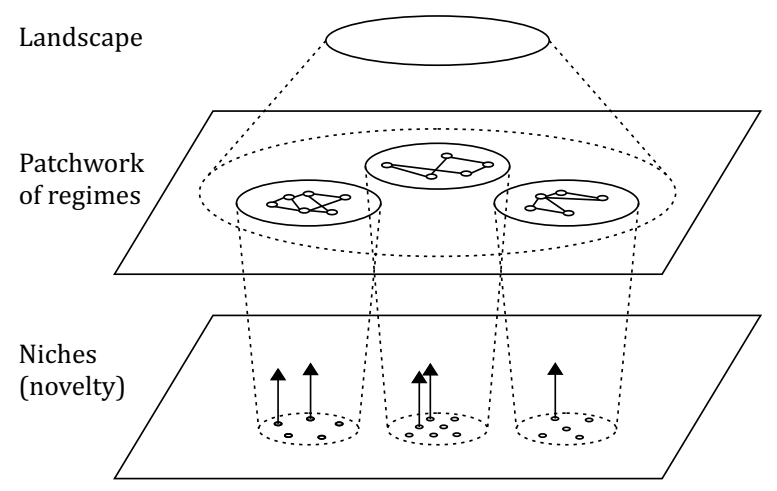

Multiple level as a nested hierarchy (Geels, 2002. p. 12GI).

Source: A Brief Introduction to the Multi-Level Perspective (MLP. Figure 1. Multi-level Perspective

\section{Innovation Systems and Factors of Innovation}

\section{Definition}

The word "innovation" is derived from the verb "innovate" which means to introduce something new and to make a change. Thus, innovation means introducing something new and inventing new ideas, devices, or methods (Merriam-Webster, 2017). Thus, innovation cannot be separated from its context which is associated with making a transition from one system to another or making development within one system.

\section{Innovation Systems}

There have been different divergent approaches which address understanding and applying the concept of innovation systems. Based on this, an innovation system theory has been invented as an analytical tool to evaluate the interaction for both quantity and quality between the mechanisms and 
the elements which make up the processes associated with innovation and their outputs like innovation and consequent diffusion. It is meant by elements of different variables like the key players who refer individuals working in an organization or concerned with shared things like management team and shareholders as well as the organizations. Other elements are attributed to knowledge, institutions, policies and innovation infrastructures like research and development and universities (Heyningen, 2016).

\section{Factors of Innovation}

What distinguishes innovation from an invention is that innovation can be more implemented. Thus, it has to be applied or used by an organization or sold in specific markets. It is not just a new technology or product. It is also a process which is determined by specific and general contextual factors in specific socio-technical environments which may contribute to making new or enhanced services or products. Based on this, four types of innovation play arole as factors of innovation: 1) Product innovation, which is attributed to the time and conditions of introducing services and products to an institution or the market. It also related to the incremental or radical improvement of the specific service or product. 2) Process Innovation is related to the improvements or changes in a process such as methods of production, methods of delivery and methods of distribution. 3) Organizational Innovation is associated with restricting the organizational functioning of an organization like workplace organization, and the innovative management which is designed to increase a firm's innovativeness. 4) Marketing Innovation is related to the important changes in marketing methods and sales and covers things like designing and packaging to enhance the consumers' appeal (Heyningen, 2016).

\section{Innovation Management}

Innovation management refers to management processes in innovation. It can be used to develop both product and organizational innovation. Without proper processes, Research and Development cannot be efficient; innovation management involves a set of tools that allow managers and engineers to collaborate to gain a common understanding of objectives and processes. The focus of innovation management is to allow the organization to seize any opportunity, whether external or internal and to use its creative efforts to present new ideas, processes or products (Kelly \& Kranzburg, 1998).

More importantly, innovation management is not limited to research and development; it involves employees and workers at all levels to participate creatively in the development, manufacture, and marketing of the company's products. By taking advantage of appropriate innovation management tools, management can stimulate and disseminate the creative values of the entire workforce for continuous company development. The process can be seen as an evolutionary integration of enterprise, technology, and the marketplace through a series of activities: research, selection, implementation and capture of opportunities (Tidd \& Bessant, 2009).

Innovation processes may be either gradual or accelerated during development. The accelerated process depends on existing or newly invented technology, so that the institution has access to it, and tries to find profitable uses of the technology. The gradual process seeks to identify aspects where customer needs have not been met, and therefore development efforts focus on finding solutions to those needs. To succeed, either way, there is a need to understand both the market and technical problems. Through the development of multi-functional development teams, including both engineers and marketing experts. With the short life of new products (or product lifecycle) regularly, increased competition forced companies to reduce time to market. Innovation managers must, therefore, reduce the time for development, without sacrificing quality or meeting market needs (Trott, 2005).

\section{Circular Economy / Sustainable Development}

The circular economy aims to separate economic growth from the use of natural resources and ecosystems by using them more effectively. It is a driving force towards innovation in the areas of 
reusing and recycling materials, components, and products; as well as new business models. In a circular economy, more efficient use of materials allows for more value creation by reducing costs, developing new markets or developing existing markets. Circular economy maintains raw materials and products in productive rings for as long as possible. It aims to eliminate waste in the industrial systems, making them less dependent on the extraction of limited resource reserves. This concept enables companies to benefit from new value sources, and also helps to create flexible markets and supply chains capable of achieving sustainable long-term prosperity (Wrap, 2013).

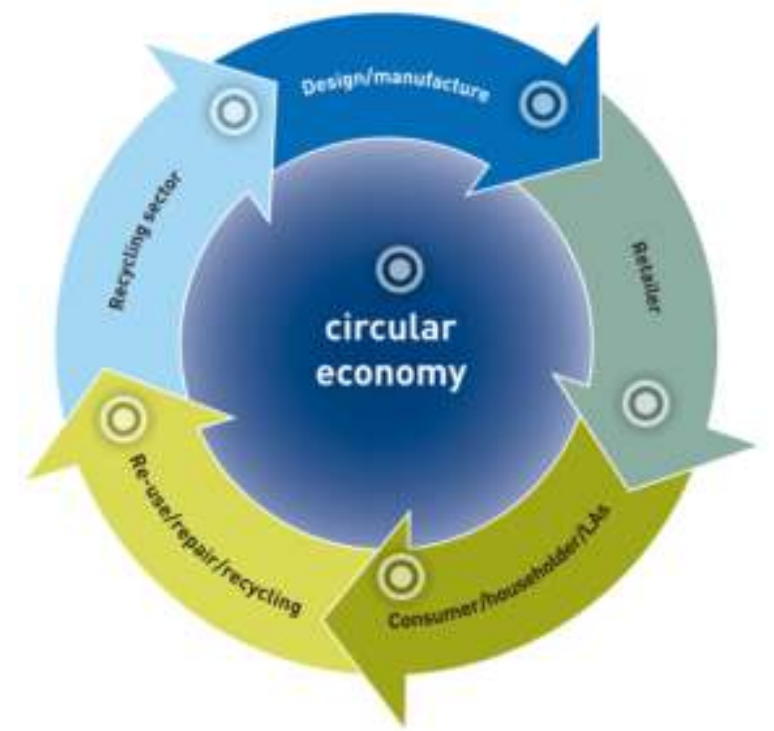

Source: Barkingside's local Agenda 21 community and environment group, (2016)

Figure2. Circular economy

Moreover, the circular business models are designed to be flexible in terms of resources because they include the physical reallocation of old products or adapt them for other purposes to serve the new demands. In addition, activities such as reuse or recycling maintain the value of the original materials and are also less exposed to energy and water risks than traditional manufacturing or recycling. Research conducted by the Resource and Waste Development Program has shown that recycling can result in a developing trade balance of $£ 90$ billion across the European Union and an additional 160,000 people in the material recovery sector (Philips, 2017).
Furthermore, the circular economy helps to create value and have positive impacts on society, environment, and economy. It helps to maintain the resources and reduce environmental impacts. While the linear economy depends mainly on a linear process for achieving high values of products and decreasing production costs on the abundant existence of raw materials at low costs, the circular economy aims at reducing environmental impacts through lowering wastes and used resources through re-using, re-cycling, reducing wastes, and re-manufacturing (Fogarassy, 2017).
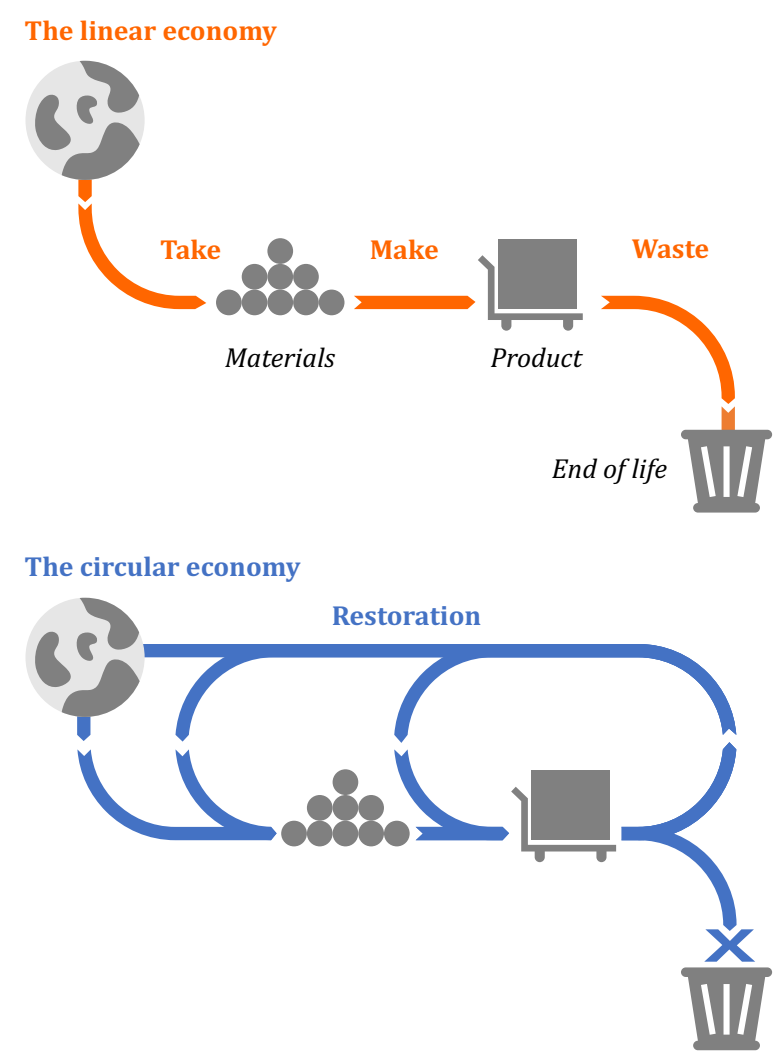

Source: Fogarassy, C. (Sept3, 201).

Figure 3. Difference between linear economy and circular economy

\section{Sustainability Transitions}

The studies associated with sustainabilityoriented technology and innovation have been increasing the last fifteen years, especially concerning sustainability transitions (Markard, Raven, \& Truffer, 2012). A sustainability transition is simply defined as " radical transformation towards a sustainable society, as a response to many persistent problems confronting contemporary modern societies" (Vanoutrive, 2013, p. 232). 
Research and reflection on sustainable cities began in the 1980s, but the term "sustainability" was used in global dialogues and debates in the 1990s, after being presented by the World Commission on Environment and Development. In particular, the crucial role played by the environmental and social dimensions of human economic activities has emerged in the creation of a better world at the Rio Earth Summit in 1992. A report that influenced these discussions was launched in collaboration between the International Union for the Conservation of Nature (IUCN), the World Wide Fund for Nature (WWF) and the United Nations Environment Program (UNEP), but changed the relevant agendas, highlighting how people build land above the environment, and focused on sustainable development (Charvekwieiz, 2001).

As the discourse of sustainability evolved, the definitions and characteristics of 'sustainable cities' began to be formulated. In the late 1990s, David Satterwhite, a leading expert in this area, suggested the city's 'successful' characteristics. David said any city should ensure a healthy life and work environment and provide infrastructure for basic services, such as clean water, sanitation, and waste management. It also argued that any city - consistent with the basic principles of sustainable development - should be in equilibrium with ecosystems, for example by ensuring the balance of groundwater bodies and reducing environmental pollution (Smith, 2017).

The definition of sustainable cities continued to develop after the 1990s, including ideas on how to use resources at present without compromising their future availability. Some suggested that all cities must meet the needs of their populations to become truly sustainable. However, the definition of urban areas remains elusive. Cities have many different characteristics. Urban areas can be classified as population overruns (population thresholds), several persons per square meter (population density), workers in the agriculture sector relative to service industries (employment ratios) or basic urban services such as water, electricity, and utilities Education and health (Hardoy, 2001).
Discussions on urban sustainability began to address spatial design and planning (known as the urban form) and 'facilitation of living' in cities; by providing affordable transport systems. The definitions of urban form have become more detailed and point to crowded, small and multiuse areas in an integrated framework of public transport, environmental policy, and management. During the URBAN21 preparatory meetings (July 2000) - one of the first global conferences devoted to urban issues - urban sustainability was defined as improving the quality of life in the city, including the environmental, cultural, political, institutional, social and economic aspects, without leaving a burden on future generations. Only a few months later, the Millennium Development Goals, including environmental sustainability, have been adopted. In 2005, the World Summit for Social Development presented the concept of the economic, social and environmental "pillars" of development. Now, with the development of the post-2015 agenda to replace the Millennium Development Goals, discussions are underway to ensure a very place for urban development in sustainable development objectives (objective 11 of the current Sustainable Development Goals project), which will ensure good planning of inclusive green cities, Flexible, productive, safe, and health (Smith, 2017).

Regarding Qatar, it is on track to become a knowledge-based economy. Sustainability issues are more important than ever. Ensuring the sustainability of economic growth is the first challenge of the third pillar (economic development) of Qatar National Vision 2030's goals: The private sector plays a key role in achieving sustainable development. Qatar's current economic sustainability is a top priority given the unprecedented growth in the country. The Qatar National Vision 2030 sets three broad and interrelated goals that will help guide and develop international and domestic policies in the coming decades: to maintain a high standard of living for all Qatari citizens, to strengthen and expand local capacities to foster innovation and entrepreneurship, and to achieve harmonization of economic outcomes with economic and financial 
security. To work towards these goals, the 20112016 Economic Development Strategy is the starting point for several projects to start transforming Qatar into a more sustainable and prosperous economy. To achieve these goals, the next five years will include progress in several initiatives: to raise the value of production base in Qatar, to strengthen economic stability, to improve technical efficiency, and to promote economic diversification (Sharq Newspaper, 2017).

\section{SAP Software System}

In this section, two areas are covered: SAP history and use, and the SAP digital circular economy business model toolkit.

\section{SAP History and Use}

SAP vision is to help the world run better and improve people's lives. The mission is to help the customers run at their best. It helps to achieve a global presence and relevance, industry and lob focus, digital economy, and innovation. Through global presence, it is possible to employ the bestqualified people from different nationalities to invest their expertise in the industry and promote the organization internationally to attract more international customers. By industry and lob focus, different solutions can be provided through SAP and utilize the web network to promote the company economy (SAP, 2017).

SAP is a German system which was firstly established in 1972. So far, it has been regarded as one of the strongest and most famous programs under "ERP". It was developed to be a comprehensive program for business sections whether small or medium companies. It is now one of the largest companies offering practical and commercial solutions. However, this system is mostly used by large companies because it is very expensive. It is a massive program of large size and especially that it focuses on how to control the calculation of costs, especially in the Finance Departments (Padhi, 2009)

SAP is an abbreviation of System, Application, and Products. It is a complete system that provides the organizations with ready-made solutions so that they can structure and connect all the departments in a single system. Thus, they can avoid or reduce the use of papers and other traditional systems. It helps users to do different tasks which include things like financial, administrative or technical tasks through computers without any other efforts, such as signing or approving documents (Padhi, 2009).

SAP can be used in both technical and functional modules. Regarding functional modules, it can be used in Advanced Business Application Programming and Basis Administrator. Regarding the technical modules, it can be used in areas like Financial \& Controlling, Sales \& Distribution, Asset Management, Human Resources, Warehouse Management, Material Management, Production Planning and Quality Management (Kogent Learning Solutions, 2010).

\section{The SAP Digital Circular Economy Business Model Toolkit}

The global environmental services industry is in the path of transition into a circular economy which transforms the business industry into closed-loop material consumption without any waste. The digital circular economy provides chances to use digital technology to create new customers experience and manage demand and supply in real-time. It also helps to optimize the execution of service and deliver outcomes of new business in a resource-constrained world (SAP, 2017).

Five technology trends contribute effectively to the digital economy. They include hyperconnectivity, supercomputing, cloud computing, a smarter world which are based on outcomes, and cybersecurity. There are three strategic areas where digital circular economy organizations adopt: business model, business procedures and work. Regarding the business model, the digital circular economy combines circular economy and digital business transformation into new innovative business models. The toolkit consists of the following archetypes: Circular business models, linear business models, enabling business models, and the digital transformation business models. 
Circular business models are important substitutes to business models in a linear "take, make, consume, dispose of" economy. The objective at production companies is to get reasonable advantages with assistance of the philosophy of the zero waste. Circular business models help decrease consuming natural resources. As for the linear business models, they are regarded classic business models which are mostly employed by recycling companies, which assume that producing waste is unavoidable, and thus it is difficult to reach zero waste. As for the enabling business models, they help to strengthen the classic linear-focused business models and circular business models. Finally, digital transformation business models enhance and enable other business models in innovating new software that help to reduce wastes and also reduces the consumption of resources such as paper (SAP, 2017).

\section{Difference Between Linear SAP and Circular SAP Solutions}

According to Bailey and Kulinna (2017), Circular SAP solutions are most effective and beneficial to the service industry, because circular economy to which most international environmental industries are transferring to is considered to be of zero waste. This is because it is featured with internet-connected sensors on waste bins. Waste components are of great important consideration to enterprises and citizens, especially that they can be reduced or recycled to maintain sustainability in terms of natural resources and materials. By comparison, a linear economy approach is considered to create big wastes as it is a "take, make, consume, and dispose of" approach.

Furthermore, circular SAP solutions contribute to transferring the economy to be circular as it transfers companies into what is known as closedloop material consumption with no wastes. Also, the products lifecycle is extended as materials are reused and recycled. Also, materials are less used as many things are based on technology for different purposes such as communication. For example, instead of using papers to communicate among business partners which are mostly used in a linear economy, internet and computer technology can be used for this purpose. Thus, consuming papers can be reduced. Accordingly, natural resources are better reserved. Circular SAP solutions can provide all these facilities through interchangeability and connectivity throughout each organizations department. This is based on the software used to provide solutions for the organization, especially regarding communication to facilitate the procedures of performing job tasks.

\section{SAP Software System in Qatar}

SAP Software System started in 2011. The main office in Qatar is called SAP Software Services LLC which is in charge of providing solutions and training for all concerned employees in the public organizations on SAP. The main current office is on the 16th floor at Alfardan Tower in West Bay in Doha (SAP MENA, 2017). Before that, Qatar economy was mostly known to be as a linear economy in different areas such as consuming materials and causing much waste. For example, piles of papers were used to communicate among the organization departments. Unwanted materials, especially consumed ones or the ones which are not much needed, were thrown and disposed of. This causes a waste of materials and even badly contributes to influencing the environment in terms of pollution and natural resources consumption.

Circular Linear SAP solutions were introduced to Qatar ministries in 2012 when called SAP Software Services LLC stared to train the employees from each ministry to use the new system in Qatar. Almost all Qatari public organizations, particularly ministries started using the software in the same year. The training lasts for 6 months (Intensive training). There were different tests after every training workshop. Also, many exams were conducted to ensure that the employees understand the new program very well, especially that it will be promoted to be used by different governmental institutions in Qatar by the year 2012. The trainers of the SAP program were from different countries. As it was bilingual (English, and Arabic) trainees from different nationalities, and cultural backgrounds benefited from it. After the training period and success in the tests and exams, 
the company provides every ministry with technical support for 3 months. The company establishes a table with days, time, dates and ministry names. So, the technical supports included assisting groups which were divided by 3 to 4 groups. Every day, there was a support to different organization in case there was any malfunction.

The program was also used by human resource departments in public organizations. The access to this program all opens just for the employees who are under the Employees Affairs section because these employees will move all the employees' information in the SAP System. So, that is to Private and confidential information of each employee would be saved and not accessed by other employees. Before the 3 months of technical support group end. According to the ministries needs and suggestion, SAP Company was decided to provide every ministry with one employee to be work in ministry every day for a year and can renew the contract to help the ministry. The training department is responsible to arrange workshops for the employees if there is any update for the program to teach them. Also, the training contains the new employees in the ministry who will be in the Human Resource department. The purpose of applying circular SAP System in the ministries is making the process easier for the employees. For example, if any employees want to ask about his next promotion, copies of certificates and Performance evaluation will be sent to him by email or uploaded to his profile in the program to view or print at any time. Circular SAP solutions do not only help in making the process of doing job tasks easier, smoother and faster.

However, they contribute effectively to the environment and economy sustainability. They help to save a lot of things which were used to be consumed and disposed of. In the linear processed before. They help to maintain many things such as paper, ink, gas consumed on cars to transfer documents and efforts. In return, they help to facilitate the process of work and give more advantages to saving wastes to a zero-level and enhancing the company productivity through better facilities and reducing costs paid on materials. Overall, at least three benefits are achieved to Qatar public organizations by adopting circular SAP solutions. One benefit is reducing wastes and maintaining natural resources. Another benefit is facilitating work processes and increasing productivity. A last but not least benefit is saving costs and contributing to organizations profitability accordingly.

\section{Use of SAP in Jordan}

SAP is one of the most powerful and most popular ERP systems, with a full suite of business software solutions that enable the company to find solutions that suit its business needs by following the best global standards in enterprise resource planning (Software advice, 2019). Some large companies in Jordan use SAP software; however, it is still expensive, especially for a small company. Yet, this depends on the workload. SAP program gives the organization high performance and accuracy. This is clear through reports that help decision-makers make better decisions. The cost of this program is very high, but compared to the results obtained, it helps to reduce costs. It helps, for example, in organizing all human and financial resources operations, calculating costs, adjusting and gradually raising the production process. It is a very professional program in performance measurement after the completion of all data. SAP is a highly efficient program in terms of data extracted from the system for all operations. It also makes the connection between all its models, saving time and effort in the work, not repeating the work and strengthening the control. Input efficiency is very important. This depends on two things that are important for the efficiency of the system administrators and the efficiency of users. The SAP system is not suitable for small businesses, because it is expensive. It is used in Jordan in large companies such as telecommunications, aviation and others (ABS, 2019).

The National Poultry Company is the first company operating in the field of poultry using this system in Jordan. Where it implemented SAP ERP. Osama Ndi, General Manager of the National Poultry 
Company said that they wanted to start implementing the SAP system, which is one of the most advanced technological programs in all the company's sites, from production to market and customers. The system helps to improve the decision-making mechanism as well as improve customer service. Nadi also explained that in today's modern management, IT has become a complete operational platform. SAP is the perfect solution to address bureaucracy and an important step for the company to keep abreast of the rapid technological development that ensures the arrival of a high-quality final product and better customer service (Alghad, 2018).

All in all, it is notable that the SAP program is a new experience in Jordan and is not implemented widely by companies. This is because SAP does not fit small businesses because it is very expensive and is suitable for large companies chiefly.

\section{RESEARCH METHODS}

\section{Research Design}

Research design is associated with the overall strategy which is chosen for the purpose of integrating specific components of the research coherently, and logically. Accordingly, this helps to ensure that the research problem is efficiently addressed. By the research design, a blueprint of the collection, measurement and data analysis is constituted (Turk, 2011). The research design adopted in this study is descriptive as it is essentially connected with searching for data that respond to the research questions through using one key method: qualitative method was a set of interview questions. Thus, this research design is a framework which was created to find answers to the questions of this research.

Qualitative type of research method helped to get more open answers which provided detailed answers to the research questions. One interview was conducted with key personnel working in Qatar and Jordan. The interview questions sought to find out information about the using SAP system and how it How is effective and created a sustainable environment in the workforce.

\section{Data collection}

The data collection was by an interview with key personal and secondary data was books, websites, and periodicals.

\section{RESULTS AND DISCUSSIONS}

Different areas associated with e mploying technology for sustainable development were discussed in this paper. These areas included Linear Innovation Model, innovation systems and factors of innovation, circular economy and sustainable development as well as sustainability transitions. as SAP software system and its applications and use in Qatar.

This section will describe the responses of the interviewees who have been interviewed by the managers of the companies from various related sectors related to the SAP system in Qatar and Jordan on the innovation systems approach to

Table 1. Summary of the responses of the managers (Respondents)

\begin{tabular}{|c|c|c|c|c|}
\hline No & Name of the company & Company Activity & Position & Important of SAP \\
\hline 1 & $\begin{array}{l}\text { The National Poultry } \\
\text { Company/ Jordan }\end{array}$ & $\begin{array}{l}\text { poultry / Industry } \\
\text { sector }\end{array}$ & General Manager & $\begin{array}{l}\text { SAP system helps to improve } \\
\text { the decision-making mechanism as } \\
\text { well as improve customer service. }\end{array}$ \\
\hline 2 & $\begin{array}{l}\text { Qatar public organizations } \\
\text { adopting to organizations }\end{array}$ & $\begin{array}{c}\text { Government public } \\
\text { organization }\end{array}$ & $\begin{array}{l}\text { Employees with } \\
\text { different position in } \\
\text { human resource } \\
\text { department from } \\
\text { different ministries }\end{array}$ & $\begin{array}{l}\text { More benefits by reducing wastes } \\
\text { and maintaining natural resources. } \\
\text { Another benefit is facilitating the } \\
\text { work processes and increasing } \\
\text { productivity. }\end{array}$ \\
\hline 3 & $\begin{array}{c}\text { Private sector such } \\
\text { as Banks }\end{array}$ & Financial fields & $\begin{array}{l}\text { Head of accounts } \\
\text { department }\end{array}$ & $\begin{array}{l}\text { Making the process of doing } \\
\text { job tasks easier, smoother } \\
\text { and faster. }\end{array}$ \\
\hline
\end{tabular}

Source: Source: (Author's own, 2019) 
sustainability transitions by using SAP Software System. The following table 1 summarizes the responses of the managers (Respondents). The researchers asked the respondents the questions through the interview conducted with key personnel working in Qatar and Jordan. The questions sought to find out information about using the SAP system and how it is effective and created a sustainable environment in the workforce.

Most of the managers agree that the SAP system considered a critical issue especially these days since IT has become a complete operational platform for all the company's sites. Particularly global companies have moved in the current era to introduce new systems that help to upgrade and organize the resources and processes resulting from the daily business and linking departments to each other. The following table 1 summarizes the responses of the managers (Respondents).

\section{The importance of research for the future}

This research will contribute to the promotion of awareness of the use of technology and innovation that will facilitate the work process and preservation of data in a sustainable environment. Through this research and to identify the views of employees in private companies and governmental organizations in Qatar and Jordan.
Also, how this system contributed to facilitating data preservation.

\section{CONCLUSION}

To conclude, Qatar and Jordan have been employing technology and development very effectively to contribute to achieving sustainability in both the economy and the environment. Employing Circular SAP solutions is one of the achievements which have been accomplished by the public organizations in Qatar, especially ministries to reduce consuming paper and extra efforts such as traditional signatures and circulations. Thus, more costs have been saved and more positive contributions to the environment have been achieved positively and creatively. However, this is not applied yet perfectly in all organizations. It is just a step on the correct way towards achieving sustainability, enhancing productivity and reaching better profitability. In Jordan, it is mainly applied in few large organizations due to its high costs.

Finally, the researchers conclude concluded from the interviews that were conducted with the respondents that the SAP system considered important issue meanwhile IT has become a complete operational platform for most companies. Since these systems helping in upgrade and organize the resources and processes and connecting departments to each other.

\section{RE F E REN C ES}

ABS (2019). SAP: Gold Partner. Retrieved April, 28, 2019 from https://www.e2abs.com/

Alghad (2018). National Poultry begins to use the global SAP system. Retrieved April, 28, 2019 from https://alghad.com/

Bailey, H. and Kulinna, R. (2017). A message to customers and partners. Retrieved December, 09, 2017 from http://www.isb-global.com/wp-content/uploads/SAP-Value-Creation-In-Digital-CircularEoncomy-Business.pdf

Barkingside's local Agenda 21 community and environment group. (March 03, 2016 ).Going Round in Circles.Retrieved from https://barkingside21.blogspot.com/2016/03/going-round-in-circles-notsuch-bad-idea.html

Charvekwieiz, E. (2001). Transitions to sustainable production and consumption: concepts, policies, and actions. Maastricht: Shaker Publishing.

Fogarassy, C. (2017). Circular Economy. SZIU: SZIU. 
Fogarassy, C. (Sept3, 201). THE IMPLEMENTATIONOF

CIRCULARECONOMYCONCEPTIN THECURRICULA. Retrieved from https://mek.unideb.hu/sites/default /files/upload_documents/dr__fogarassy_csaba_eloadasa.pdf

Fogarassy, C. (2017). The Theoretical Background of Circular Economy and the Importance of it's Application at Renewable Energy Systems The Theoretical Background of Circular Economy and the Importance of it's Application at Renewable Energy Systems. Retrieved from

https://www.researchgate.net/publication/319403544_The_Theor etical_Background_of_Circular _Economy_and_the_Importance_of_it's_Application_at_Renewable_Energy_Systems_The_Theoretic al_Background_of_Circular_Economy_and_the_Importance_of_it's_Application_

Geels, F. W. (2011). The multi-level perspective on sustainability transitions: Responses to seven criticisms. Environmental Innovation and Societal Transitions, 1(1), 24-40. https://doi.org/10.1016/j.eist. 2011.02.002

Godin, B. (2005). The Linear Model of Innovation: Retrieved from http://www.csiic.ca/PDF/Godin_30.pdf

Hardoy, J. (2001). Environmental problems in an urbanizing world. London: Routledge.

Heyningen, J. (2016). An innovation systems approach to sustainability transitions. Stellenbosch University, Stellenbosch.

Kelly, P., \& Kranzburg, M. (1998). Technological Innovation: A Critical Review of Current Knowledge. San Francisco: San Francisco Press.

Markard, J., Raven, R., \& Truffer, B. (2012). Sustainability transitions: An emerging field of research and its prospects. Research Policy, 41(6), 955-967.https://doi.org/10.1016/j.respol.2012.02.013

Merriam-Webster. (2017). Definition of INNOVATION. Retrieved November 11, 2017, from https://www.merriam-webster.com/dictionary/innovation

Miles, C. (2014, October 6). Multi-Level Perspective (MLP). Retrieved November 10, 2017, from https://marchudson.net/multi-level-perspective-mlp/

Padhi, S. N. (2009). SAP® ERP Financials And FICO Handbook. Boston: Jones \& Bartlett Learning.

Philips, P. (2017). The transition from a linear to a circular economy. Retrieved November 11, 2017, from https://www.philips.sa/en/a-w/innovationandyou/article/extended-story/circulareconomy.html

SAP (2017). Value creation in digital circular economy business. Retrieved December, 01, 2017 from http://www.isb-global.com/wp-content/uploads/SAP-Value-Creation-In-Digital-CircularEoncomy-Business.pdf

SAP MENA. (2017). Worldwide Office Locations | Qatar. Retrieved November 14, 2017, from https://www.sap.com/corporate/en/company/office-locations/qatar.html

Sharq Newspaper. (2017). Qatar is moving towards a knowledge economy. Retrieved from http://www.alsharq.com/news/details/523017

Smith, P. (2017). Transforming cities for sustainability: Facts and figures. Retrieved from http://www.scidev.net/mena/cities/feature/transforming-cities-sustainability-facts-figuresAR.html

Software advice (2019). ERP Software. Retrieved April, 28, 2019 from https://www.softwareadvice.com/erp

T. Steward.(November,2012). A Brief Introduction to the Multi-Level Perspective (MLP. Retrieved from projects.exeter.ac.uk/igov/wp-content/uploads/2012/12/DOWNLOAD-Multi-LevelPerspectives.pdf

Tidd, J., \& Bessant, J. (2009). Managing Innovation: Integrating Technological, Market and Organizational Change. New Jersey: Wiley.

Trott, P. (2005). Innovation Management and New Product Development. New Jersey: Prentice Hall.

Vanoutrive, T. (2013). Smart Transport Networks. Edward Elgar Publishing.

Wrap, U. (2013, January 24). WRAP and the circular economy. Retrieved November 11, 2017, from http://www.wrap.org.uk/about-us/about/wrap-and-circular-economy 